\title{
Comfortable Liveable Space: Shipping Container and Bamboo as Sustainable Building Materials in Equatorial Climate Perspective?
}

Adi Ainurzaman Jamaludin

Environmental Science and Management Programme, Institute of Biological Sciences, Faculty of Science, Universiti Malaya, 50603 Kuala Lumpur.

Zul Ilham

Environmental Science and Management Programme, Institute of Biological Sciences, Faculty of Science, Universiti Malaya, 50603 Kuala Lumpur.

Wan Abd Al Qadr Imad Wan-Mohtar

Functional Omics and Bioprocess Development Laboratory, Institute of Biological Sciences, Faculty of Science, Universiti Malaya, 50603 Kuala Lumpur.

Sarina Abdul Halim-Lim

Faculty of Food Science and Technology, Universiti Putra Malaysia, 43400 Serdang, Selangor.

\section{Hazreena Hussein}

Department of Architecture, Faculty of Built Environment, Universiti Malaya, 50603 Kuala Lumpur.

\section{ABSTRACT}

The development of liveable space made from shipping containers becomes a trend even in Malaysia with the hot and humid climate persisting throughout the year. For sustaining the indoor comfort, building insulation is well adapted to increase thermal resistance and reduce the dependency on the mechanical cooling systems. The prospective of a shipping container as an efficient construction material and bamboo as a sustainable insulation material is well documented but basic information on the internal environment that has an impact on a person, particularly risk potential towards sick building syndrome (SBS) has been absent. Therefore, the measurements of both indoor and outdoor temperatures, relative humidity and $\mathrm{CO}_{2}$ concentration with two different conditions were done by using different sets of data loggers for at least 70 days under each condition. The first condition is a bare unit of the shipping container and followed by the installation of untreated bamboo as insulation for the second condition. This research reveals that high temperatures were recorded up to $40^{\circ} \mathrm{C}$ in both conditions and untreated bamboo as insulation increased the relative humidity levels up to the maximum, $100 \%$. The mean values of $\mathrm{CO}_{2}$ concentration are in the range of $1,869 \mathrm{ppm}$ to $2,938 \mathrm{ppm}$ and they reach up to $5,000 \mathrm{ppm}$ at the most of the intervals, indicating a significant contribution to SBS. The condition of the equatorial climate denies the compatibility of the shipping container to be used as the building material of liveable space. The quality and treatment of the bamboo must be the ultimate priority.

\section{Article History}

Received : 02 November 2020

Received in revised form : 10 February 2021

Accepted : 18 February 2021

Published Online : 30 April 2021

Keywords:

Bamboo, Comfort, Insulation, Shipping Container, Sick Building Syndrome

Corresponding Author Contact:

adiainurzaman@um.edu.my

DOI: $10.11113 /$ ijbes.v8.n2.728

(C) 2021Penerbit UTM Press. All rights reserved 


\section{Introduction}

The use and the transformation of a shipping container as a liveable space have grown drastically all around the world. It is not limited to residential and commercial structures but extended to various kinds of buildings and functions including school buildings, studios, shops, mobile museums, bank branches, medical buildings, pharmacies, sleeping rooms, cultural centers, malls and public restrooms (Radwan, 2015). The surplus of shipping containers due to the imbalanced trade of western-Asian countries that lowered their price and the lack of affordable housing for students in the city of Amsterdam urged the conversion of a shipping container into 1,000 units of student housing (Uittenbroek and Macht, 2009). The very high embodied energy of the shipping container encourages the recycling process to maintain ecological sensitivity (Vijayalaxmi, 2010).

In natural disaster areas, the shipping container has become an interim house for the homeless (Hong, 2017). The need for this sustainable temporary house is expected to increase due to the increasing severity of natural disasters resulting in the large number of displaced peoples, an increase in the number of climate refugees as a result of a changing climate and the inability of developing countries to provide sufficient infrastructure to keep pace with their rapid population growth (Perrucci et al., 2016). A study done by Zhang et al. (2014), found that the success of shipping container temporary housing projects relate to the flexibility in ownership, and reuse, while the sitting arrangement is significant with key social factor, in addition to robust predisaster planning by authorities, taking into account the varying characteristics of different types of disasters.

The characteristics of a shipping container which is high structural strength, easily recycled and reused with a wide range of sources make it a great material in the construction of liveable space (Sun et al., 2017). As-built with stringent standards of design and size, it brings the advantages of modularity, ease of transport and assembly (Pena and Schuzer, 2012). According to Oloto and Adebayo (2012), the shipping container is able to withstand the stacking of nine fully laden containers and extreme weather conditions. The construction time and cost can be reduced due to unnecessary additional resources, planning and maintenance either for initial construction or further expansion (Radwan, 2015). Thus, the shipping container is a mark of construction efficiency, affordability, economy, mobility and sustainability (Buchmeier et al., 2010; Martinez-Garcia, 2014). In the long term, it gives an impact on the real estate industry when the container-housing trend will likely continue to gain momentum due to the increasing demand for affordable houses (Martinez-Garcia, 2014).

The shipping containers are made of steel and were designed to improve the quality and efficiency of naval vehicular in the $1950 \mathrm{~s}$ (Levinson, 2016). The structural compositions of the shipping container are container base with cross member and plywood flooring, door assembly, rear-end frame, top-side rail with side panel assembly, front-end frame and roof panel (Radwan, 2015; Ismail et al., 2015). The main function is for shipping goods and to store products. The most common size of shipping containers are 20', 40', 20' High Cube (HC), 40' $\mathrm{HC}$ and 45' HC with $2.4 \mathrm{~m}$ of width, and in the range between $2.4 \mathrm{~m}$ and $2.9 \mathrm{~m}$ of heights (Bernardo et al., 2013; ISO 688:1995). The 20' HC container is always a preferred choice for construction building due to its greater strength, lower price and ideal clear ceiling height of $2.4 \mathrm{~m}$ that provides a space for hiding the ductwork, plumbing and electricity (Ismail et al., 2015).

The use of shipping containers in building industries is well accepted in Malaysia with the growth of container-style hotels, especially at tourist attraction places outside the city area (Adreena, 2017; Alaniazul, 2016; KL Now, 2016). By staying in this new concept of hotels, it gives a unique experience while people can enjoy the tranquillity of the countryside and the beauty of nature. In order to sustain the indoor comfort, a mechanical cooling system is required due to Malaysia's climatic conditions that are hot-humid throughout the year (Ahmad, 2008). As located in the equatorial climate region, high temperature and relative humidity are recorded throughout the year with heavy rainfall, especially during the changes of monsoon. Air conditioning systems are fully utilised, which increase the electricity usage and extend the effect of global warming. This situation is getting worse as the shipping container is mainly made of steel, which has high heat conductivity and without sufficient insulation; it is prone to condensation (Botes, 2013). Thus, insulation is a necessity to avoid heat for sustaining the comfort level with the minimum usage of energy for the mechanical cooling system. Furthermore, it can prevent noise, fire, pollution and any invasion by threatening creatures like poisonous animals (Wagner, 2017).

Building insulation is an effective way of energy conservation by increasing the thermal resistance of the building envelope, and it is classified according to the heat exchange properties, form, and composition (Aditya et al., 2017). Conventionally, building insulation is obtained from petrochemicals or natural sources processed with high energy consumption (Asdrubali et al., 2015). There are six common insulation materials in Malaysia, namely rock wool, fiberglass, urethane, fiberglass urethane, perlite, and extruded polystyrene (Basrawi et al., 2013). Due to the movement on environmental-friendly buildings, there are several feasibility studies on agricultural and industrial by-products as new sustainable insulation materials (Asdrubali et al., 2015; Volf et al., 2015; Chuen et al., 2015). These are also contributed by the need for maximising energy saving, for low material cost, easy manufacture and application in the building structure (Reif et al., 2016; Moghimi et al., 2013).

Bamboo is one of the fastest-growing plants, which makes it ideal as a sustainable construction material (Bal et al., 2010). Jusoh et al. (2013) showed two species of bamboo which are Akar bamboo (Dendracalamus pendulus) and Semantan bamboo (Gigantochloa scortechinii) with low thermal conductivity. A similar result is also reported by using Guadua velutina and with low thermal diffusivity, it is possible to combine with other materials as insulation (Gallegos-Villela et al., 2016). By not referring to specific species, two lines of bamboo as multilayer wall is convenient as a material construction with a U-Value of 1.4 $\mathrm{W} / \mathrm{m}^{2} \mathrm{~K}$ and three layers is recommended to mitigate the presence of thermal bridges with a U-Value of $0.67 \mathrm{~W} / \mathrm{m}^{2} \mathrm{~K}$ 
(Bruges et al., 2018). Fiberboards from bamboo fibers and protein-based bone glues have shown a great potential for buildings thermal insulation with a thermal conductivity below $0.082 \mathrm{Wm}^{-1} \mathrm{~K}^{-1}$ (Nguyen et al., 2018). As compared to woodbased shear walls, the thermal insulation performance of bamboo shear walls is slightly lower, demonstrating their feasible substitution in common practice (Wang et al., 2018). The benefits of bamboo, especially in the construction of affordable structures are well documented by Nwoke and Ugwuishiwu (2011).

From the safety and health perspective, indoor air quality has been highlighted as one of the main aspects that contribute to SBS under building-related factors (Wijerathne et al., 2012). Snow et al. (2019) showed substantial links exist between the prevalence of SBS and elevation of indoor $\mathrm{CO}_{2}$ concentrations. As stated by Apte et al. (2000), the indoor $\mathrm{CO}_{2}$ concentration is approximately the surrogate for indoor concentrations of other occupant-generated pollutants and the ventilation rate per occupant. By keeping $\mathrm{CO}_{2}$ concentrations below 1,000 ppm, it is able to improve the occupants' task performance (Hong et al., 2018).

SBS is a situation where the occupants of a building experience acute health or comfort-related effects that seem to be linked directly to the time spent in the building (Joshi, 2008). Six factors are related to increasing the prevalence of SBS, which are personal factors, job category, type of work, psychosocial factors, building factors and building-related factors (Skov et al., 1990; Burge, 2004; Crook and Burton, 2010). According to Wijerathne et al. (2012), personal, psychosocial and building-related factors are the most common affecting factors leading to SBS. The signs and symptoms of SBS comprise a group of unclear aetiology divided into mucous membrane symptoms related to the eyes, nose, and throat; dry skin; together with what are often called general symptoms of headache and lethargy (Burge, 2004; Fisk et al., 2009). Joshi (2008) listed cough, chest pain, shortness of breath on mild exertion, edema, palpitations, nosebleeds, cancers, pregnancy problems, miscarriages, extrinsic allergic alveolitis, Legionnaire's disease, humidifier fever, pneumonia, and occupational asthma as the signs and symptoms of SBS specifically to the building-related factors.

There is a lack of studies on the effectiveness of bamboo as insulation for liveable space constructed from shipping containers. The internal condition of shipping containers that are exposed to high temperatures and humidity of the equatorial climate is undefined to be referred to as a baseline. To date, an engineered solution to the problem that is low-cost, quick to construct, environmentally and socially sustainable, that takes into account the needs of the occupant, and accounts for local climatic conditions has yet to be found (Perrucci et al., 2016). Thus, this research aims to examine the indoor and outdoor conditions of a shipping container by focusing on two basic parameters, which are temperature and relative humidity. The measurements were carried out simultaneously before and after the installation of untreated bamboo functioning as insulation. The carbon dioxide $\left(\mathrm{CO}_{2}\right)$ level was also observed but it is limited inside the shipping container. According to Jaber et al. (2017), temperatures and indoor $\mathrm{CO}_{2}$ levels within buildings play a crucial role for occupant performance particularly cognitive performance regarding all mental activities including thinking, reasoning and remembering. The findings from this research reveal the suitability of shipping containers to be utilised as a liveable space and bamboo as an insulator, especially in the equatorial climate region. In the long term, they contribute to the efficient use of electricity due to the low thermal loads for sustaining the comfort level while minimising the air contamination.

\section{Methodology}

The research was conducted in a closed 20' shipping container and painted with basic white colour without any ventilation to minimise any other factors that would affect the measurements of temperature $\left({ }^{\circ} \mathrm{C}\right)$, relative humidity $(\%)$ and $\mathrm{CO}_{2}$ concentration (ppm). The Onset Hobo $\mathrm{MX} \mathrm{CO}_{2}$ logger was located in the middle of a shipping container by using a tripod. This data logger is using a non-dispersive infrared (NDIR) self-calibration $\mathrm{CO}_{2}$ sensor technology with integrated temperature and RH sensors. Thus, erroneous results can be avoided while keeping the operating and maintenance cost to a minimum (Onset, 2017).

Outside the shipping containers, the measurement only involves the temperature $\left({ }^{\circ} \mathrm{C}\right)$ and relative humidity (\%) due to the restricted capability of equipment. Onset Hobo Micro Station H21-002 data logger that is connected to the sensor covered by the solar radiation shield was used by fixing it at one steel pole. As shown in Figure 1, all data loggers and sensors were fixed at $1.10 \mathrm{~m}$ above the floor as the typical human body level (Jamaludin et al., 2017).
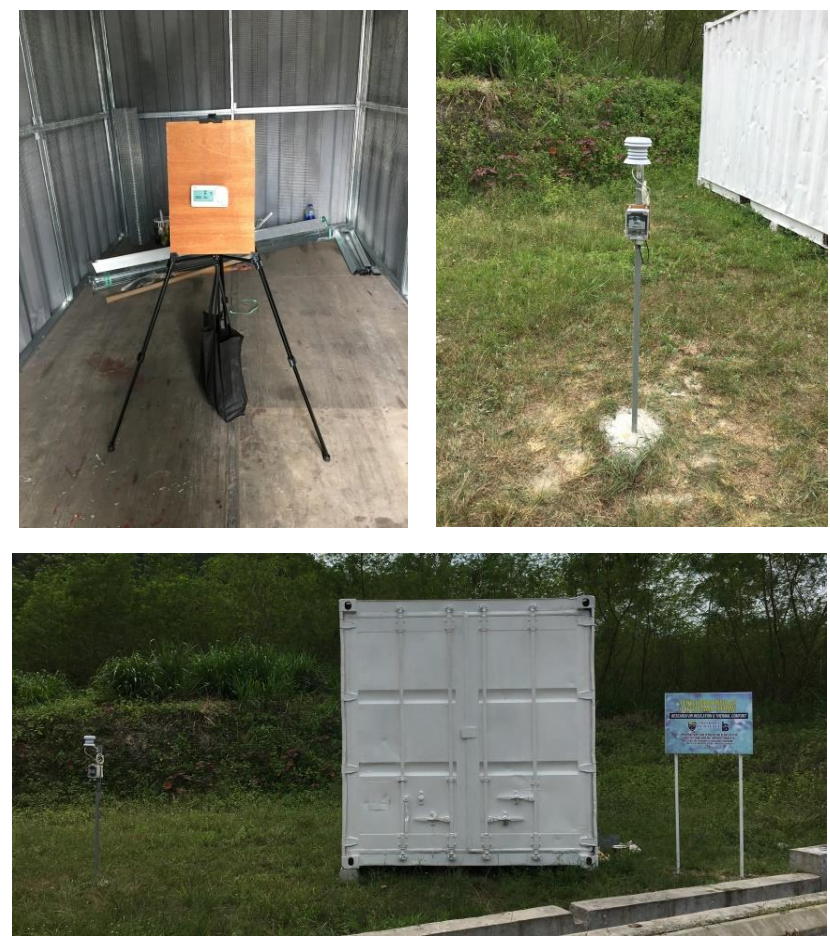

Figure 1 The arrangement of equipment for both inside and outside the shipping container 
The measurements were done two times with different conditions at least for 70 days for each condition. The first condition is a bare unit of the shipping container (BUSC) and the second condition is installed with untreated bamboo as insulation at all sidewall panels, end wall panel, roof panel, and door assembly (IUBSC) as shown in Figure 2. In both conditions, there is no modification done for the flooring that is covered with plywood.

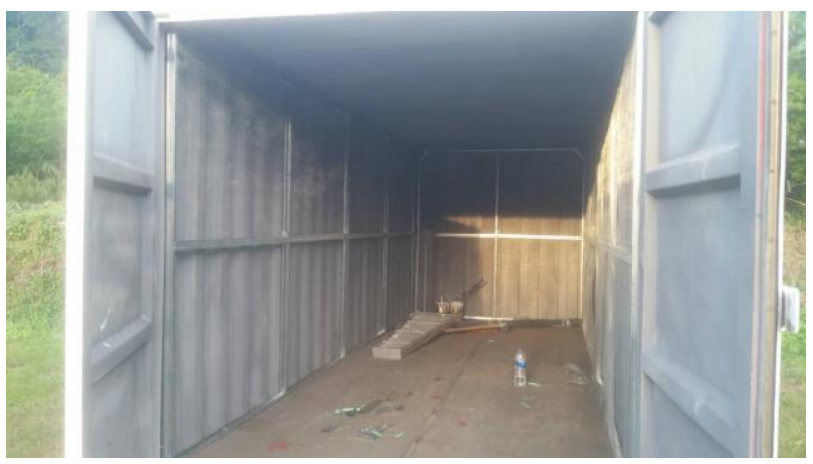

(a)

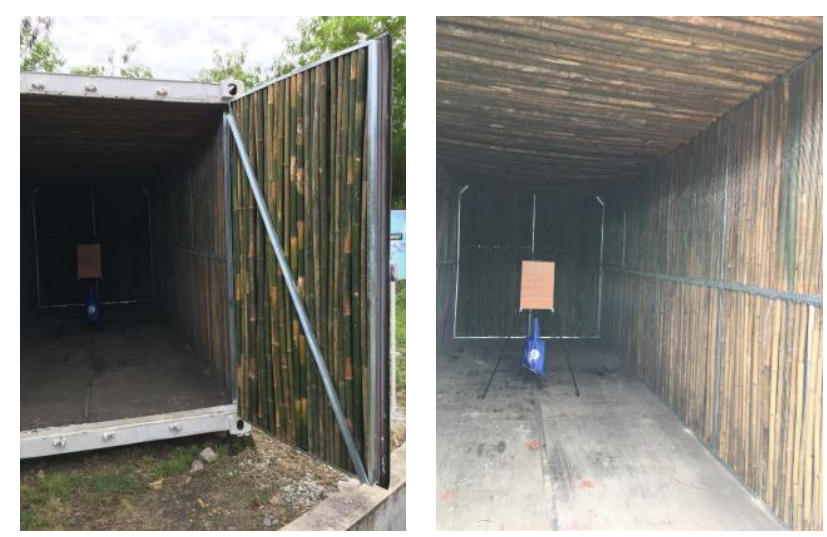

(b)

Figure 2 The arrangement of (a) bare unit of shipping container BUSC, (b) shipping container installed with untreated bamboo as insulation - IUBSC

The data loggers were set to cover a 24-hour measurement with a one-hour interval due to the uniformity of Malaysia's climatic conditions throughout the year and it has distinguishable differences caused by the day and night factor (Ahmad, 2008; Jamaludin et al., 2017; Dahlan et al., 2009).

As the measurement of both conditions (BUSC \& IUBSC) was not done concurrently, the effectiveness of bamboo as insulation for liveable space constructed from shipping containers was recognised based on the difference values of temperature and relative humidity between inside and outside of the shipping container according to the daily pattern or 24 hours' average profile. Further statistical analyses were carried out by using a statistical computer software package to determine the difference of measurements of situations which are, between the inside and outside of the shipping container and between two conditions (BUSC \& IUBSC), as well as the $\mathrm{CO}_{2}$ concentration between a bare unit of the shipping container and shipping container that is insulated by untreated bamboo.

\section{Results and Discussion}

\subsection{Temperature and Relative Humidity}

The measured temperature and relative humidity values for indoor and outdoor under both conditions (BUSC \& IUBSC) are presented in Figure 3 and 4. The measurement covered a 24-hour with a one-hour interval from Day 1 until Day 70. In a bare unit of a shipping container (BUSC), the recorded indoor temperatures are in a range of between $18.72^{\circ} \mathrm{C}$ and $42.24^{\circ} \mathrm{C}$. A smaller range can be observed at the outside when minimum and maximum values are $19.51^{\circ} \mathrm{C}$ and $36.12^{\circ} \mathrm{C}$, respectively.

The measured values for indoor relative humidity are in the range of between $56.65 \%$ and $90.12 \%$, while outdoor has a margin of $42.50 \%$ to $100 \%$. With the installation of untreated bamboo as insulation (IUBSC), the maximum indoor relative humidity values can exceed $100 \%$. The smaller range was observed as the minimum value was $92.06 \%$. Comparatively, there was a bigger range at the outside as minimum and maximum values were $45.40 \%$ and $100 \%$. With regard to the temperature, the minimum and maximum temperature values were $18.72^{\circ} \mathrm{C}$ and $40.80^{\circ} \mathrm{C}$ for the inside, while $18.79^{\circ} \mathrm{C}$ and $35.93^{\circ} \mathrm{C}$ were for the outside of the shipping container.

The difference between the measured temperature and relative humidity values according to the daily pattern or 24 hours' average profile between the inside and outside of the shipping container concerning both conditions (BUSC \& IUBSC) is visualised in Figure 5 and 6. Extracted from Figure 4 and 5, the minimum and maximum values with differences according to time are presented in Table 1.

The installation of bamboo as insulation contributes to the reduction of the temperature inside the shipping container. The differences between minimum and maximum values are getting lesser as compared to the values measured inside a bare unit of a shipping container (BUSC). On average, the maximum value exceeds $35^{\circ} \mathrm{C}$ at $1 \mathrm{pm}$, while $31^{\circ} \mathrm{C}$ has been recorded at the outside a bare unit of a shipping container. The difference exceeds $4^{\circ} \mathrm{C}$ at $2 \mathrm{pm}$. With regard to the second condition (IUBSC), both indoor and outdoor show a similar value which is $30^{\circ} \mathrm{C}$ at $3 \mathrm{pm}$ with $2.5^{\circ} \mathrm{C}$ of maximum difference at $8 \mathrm{pm}$. By looking at the outdoor relative humidity, the values are constant between $68 \%$ and $99 \%$ throughout the research. For indoor, the relative humidity values are influenced by temperature as the increased temperature can decrease the relative humidity values. Remarkably, a substantial difference of up to $30 \%$ was obtained on the second condition due to high minimum and maximum values that reached $99 \%$ although in the afternoon.

Referring to Table 2, further statistical analysis shows that there is a significant difference of two measured parameters; temperature $(\mathrm{t}=-19.006, \mathrm{df}=1,701, \mathrm{p}<.05)$ and relative humidity $(\mathrm{t}=$ $34.495, \mathrm{df}=1,701, \mathrm{p}<.05)$, between the indoor and outdoor of a bare unit of shipping container (BUSC). 


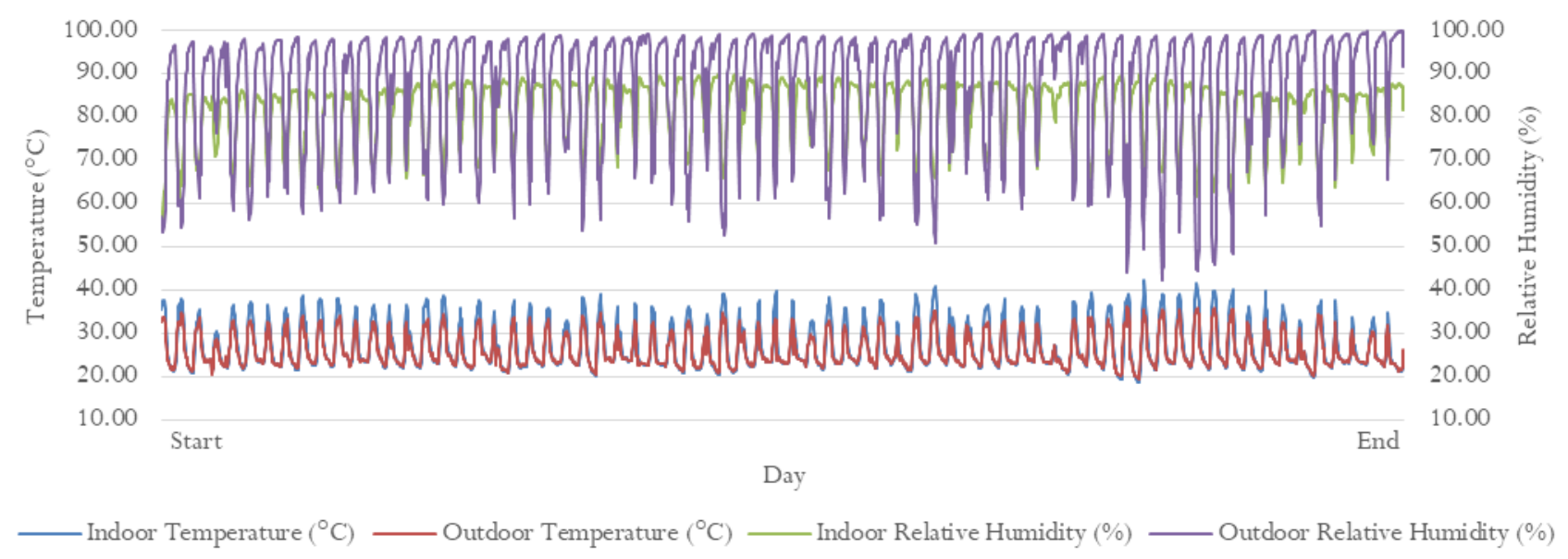

Figure 3 The measured indoor and outdoor temperature and relative humidity values of the bare unit of shipping container

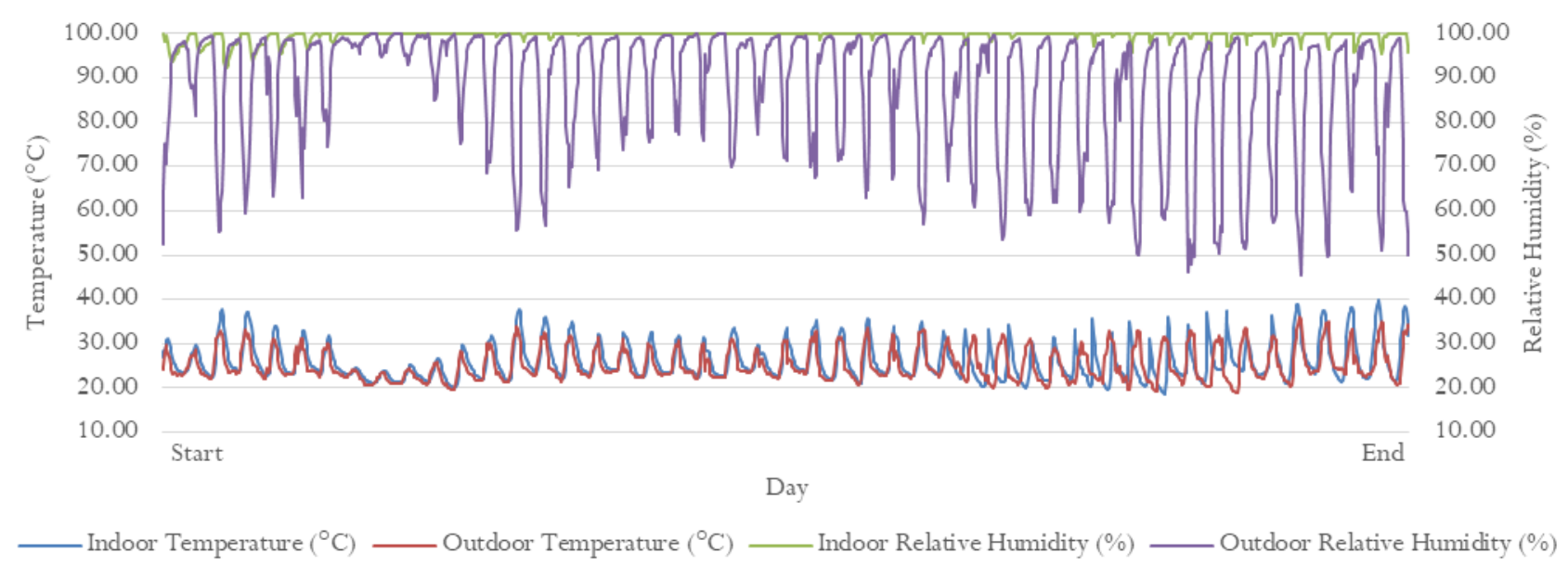

Figure 4 The measured indoor and outdoor temperature and relative humidity values of the shipping container installed with untreated bamboo as insulation

Similar result was also obtained for the second condition (IUBSC) with a significant difference of temperature $(\mathrm{t}=-8.464, \mathrm{df}=$ $1,108, \mathrm{p}<.05)$ and relative humidity $(\mathrm{t}=-26.845, \mathrm{df}=1,108, \mathrm{p}$ $<.05)$.

High-temperature values were recorded up to $40^{\circ} \mathrm{C}$ in both conditions, a bare unit of a shipping container (BUSC) and with the installation of untreated bamboo as insulation (IUBSC). The installation of untreated bamboo pushes relative humidity values to the maximum exceeding $100 \%$. With this humidity level, the bamboo begins to decay as the highest strength occurred in environments with the humidity level in the range of 60 to $80 \%$ and the level significantly dropped thereafter (Askarinejad et al., 2015). The decay process was accelerated as some of the bamboos are probably immature when they were harvested, which indirectly affects the strength of the bamboo. The optimum maturity period of bamboo is about three to four years to provide optimum strength (Sekhar and Bhartari, 1960). Through periodic observation, the decay process is getting faster with the absence of any treatment to the bamboo that is used as insulation in this research. As reported by Bruges et al. (2018), it is necessary to apply some treatments to the bamboo for waterproofing, fire resistance and avoiding the presence of animals that can damage it.

Comparatively, the findings on the daily pattern or 24 hours' average profile are out of the comfort ranges that have been lined up either by global or local authorities. American Society of Heating, Refrigerating and Air Conditioning Engineers - ASHRAE has set the temperature and relative humidity in the range of $23^{\circ} \mathrm{C}$ to $25^{\circ} \mathrm{C}$ and $20 \%$ to $60 \%$, while Standards and Industrial Research Institute of Malaysia - SIRIM MS 1525 in the range of 22 to $26^{\circ} \mathrm{C}$ and 30 to $70 \%$ respectively (Jamaludin et al., 2017). The daily pattern is also not acceptable to any range of comfort for Malaysians as reported by AbdulRahman (1997) and ZainAhmed et al. (2004) who give a range of 23.4 to $28^{\circ} \mathrm{C}$ of temperature and 54 to $76 \%$ of relative humidity. Hidayat and Munardi (2018) found that commercial facilities using a shipping container are less convenient for humans and animals especially cats and dogs as a standard recommendation for temperature and relative humidity indicated by American Veterinary Medical Association (AVMA) is in the range of between 15.5 to and $26.6^{\circ} \mathrm{C}$ and between 30 and $70 \%$, respectively. 


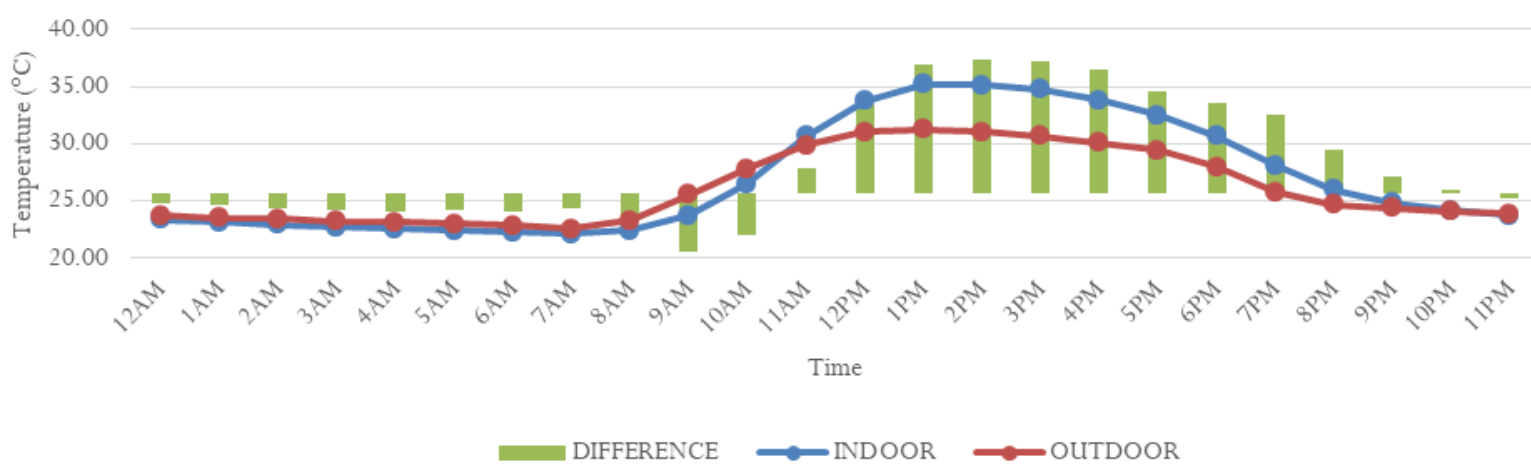

5.00

(a)

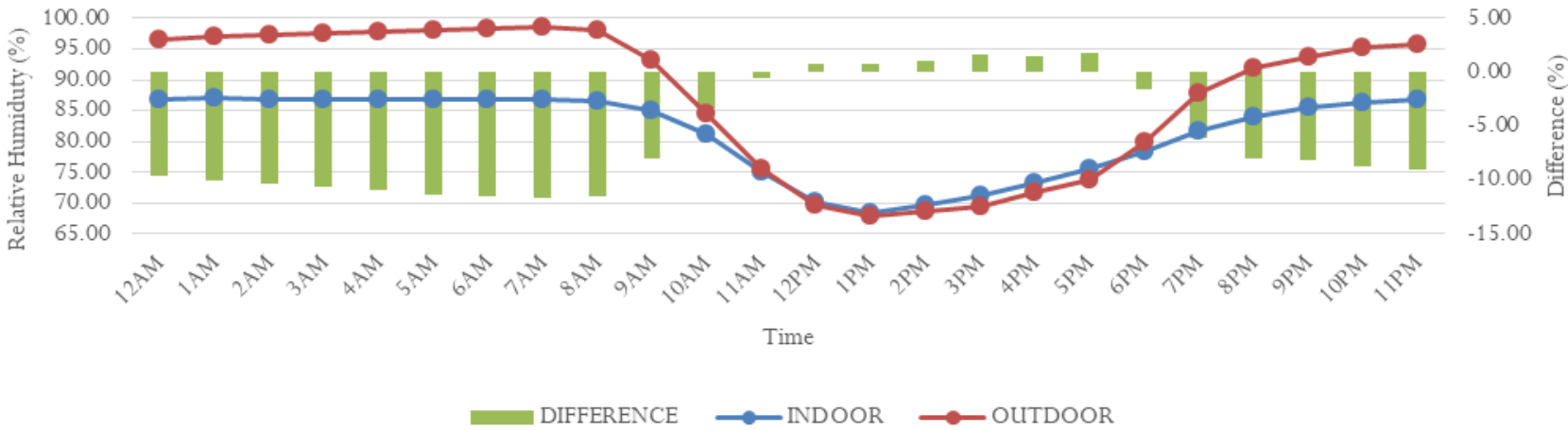

(b)

Figure 5 The daily pattern of indoor and outdoor (a) temperature, (b) relative humidity of the bare unit of shipping container (BUSC)

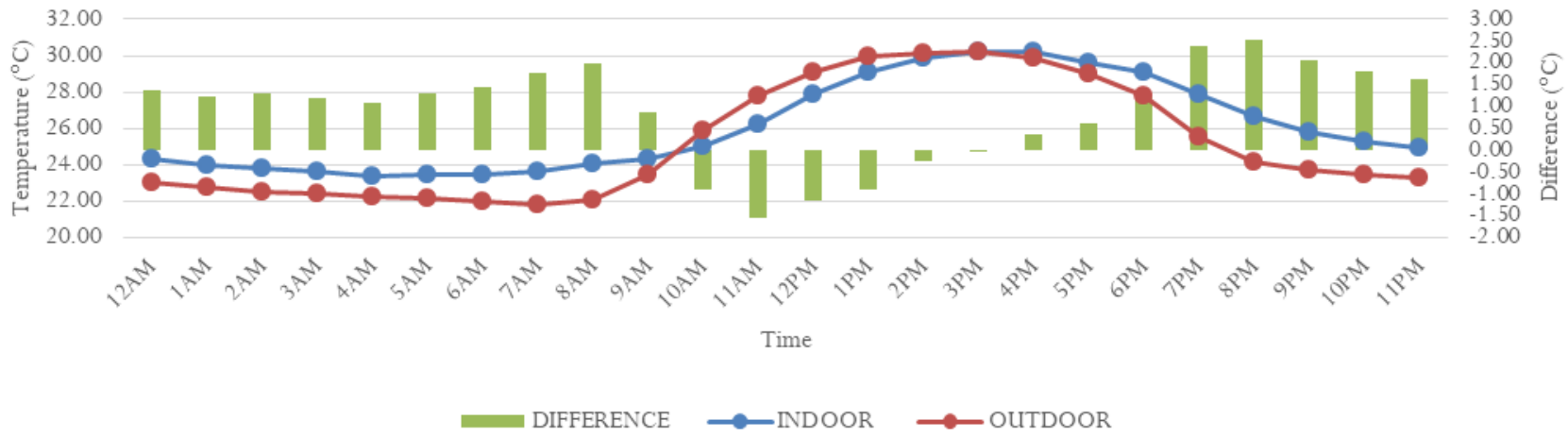

(a)

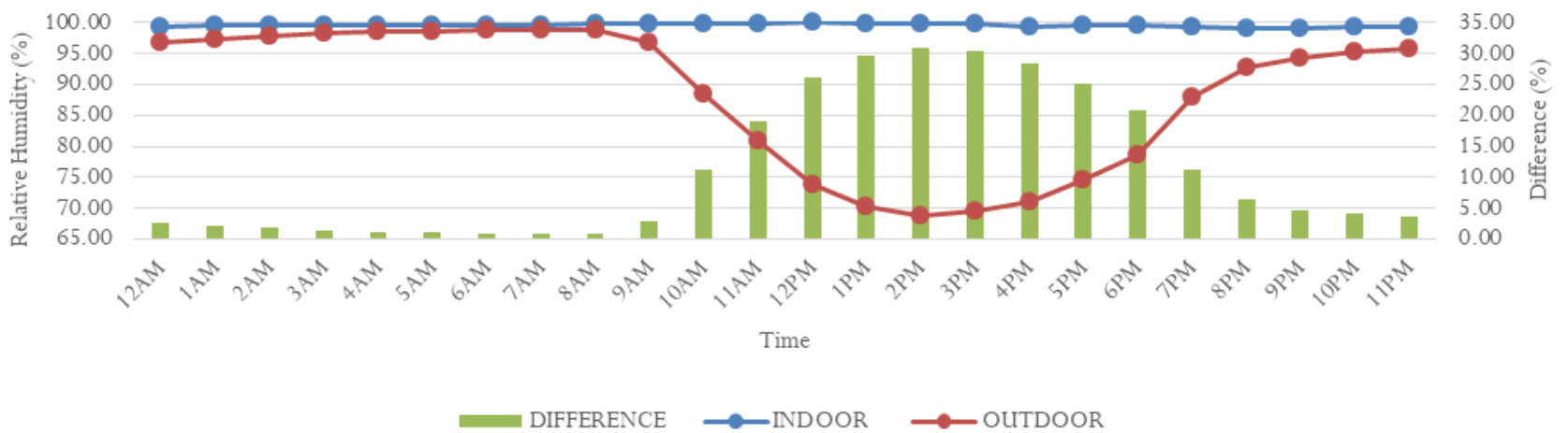

(b)

Figure 6 The daily pattern of indoor and outdoor (a) temperature, (b) relative humidity of the shipping container installed with untreated bamboo as insulation (IUBSC) 
Table 1 The minimum and maximum values of temperature and relative humidity according to different conditions - bare unit of shipping container (BUSC) and shipping container installed with untreated bamboo as insulation (IUBSC)

\begin{tabular}{|c|c|c|c|c|c|}
\hline & & \multicolumn{4}{|c|}{ Condition } \\
\hline & & \multicolumn{2}{|c|}{ Bare unit (BUSC) } & \multicolumn{2}{|c|}{$\begin{array}{l}\text { Installed with untreated bamboo as insulation } \\
\text { (IUBSC) }\end{array}$} \\
\hline & & Temperature $\left({ }^{\circ} \mathrm{C}\right)$ & Relative Humidity (\%) & Temperature $\left({ }^{\circ} \mathrm{C}\right)$ & Relative Humidity (\%) \\
\hline \multirow[t]{2}{*}{ Indoor } & Min & $22.15(7 \mathrm{am})$ & $68.53(1 \mathrm{pm})$ & $23.35(4 \mathrm{am})$ & $99.10(9 \mathrm{pm})$ \\
\hline & Max & $35.18(1 \mathrm{pm})$ & $86.95(1 \mathrm{am})$ & $30.22(3 \mathrm{pm})$ & 99.98 (12pm \& 1pm) \\
\hline \multirow[t]{2}{*}{ Outdoor } & Min & $22.61(7 \mathrm{am})$ & $67.78(1 \mathrm{pm})$ & $21.84(7 \mathrm{am})$ & $68.89(2 \mathrm{pm})$ \\
\hline & Max & $31.24(1 \mathrm{pm})$ & $98.45(7 \mathrm{am})$ & $30.25(3 \mathrm{pm})$ & $98.96(8 \mathrm{am})$ \\
\hline \multirow[t]{2}{*}{ Difference } & Min & $-1.83(9 \mathrm{am})$ & $-11.67(7 \mathrm{am})$ & $-1.57(11 \mathrm{am})$ & $0.82(8 \mathrm{am})$ \\
\hline & Max & $4.09(2 \mathrm{pm})$ & $1.81(5 \mathrm{pm})$ & $2.53(8 \mathrm{pm})$ & $31.06(2 \mathrm{pm})$ \\
\hline
\end{tabular}

Table 2 Paired samples statistical analysis of indoor-outdoor temperature and relative humidity values of two different conditions - bare unit of shipping container (BUSC) and shipping container installed with untreated bamboo as insulation (IUBSC)

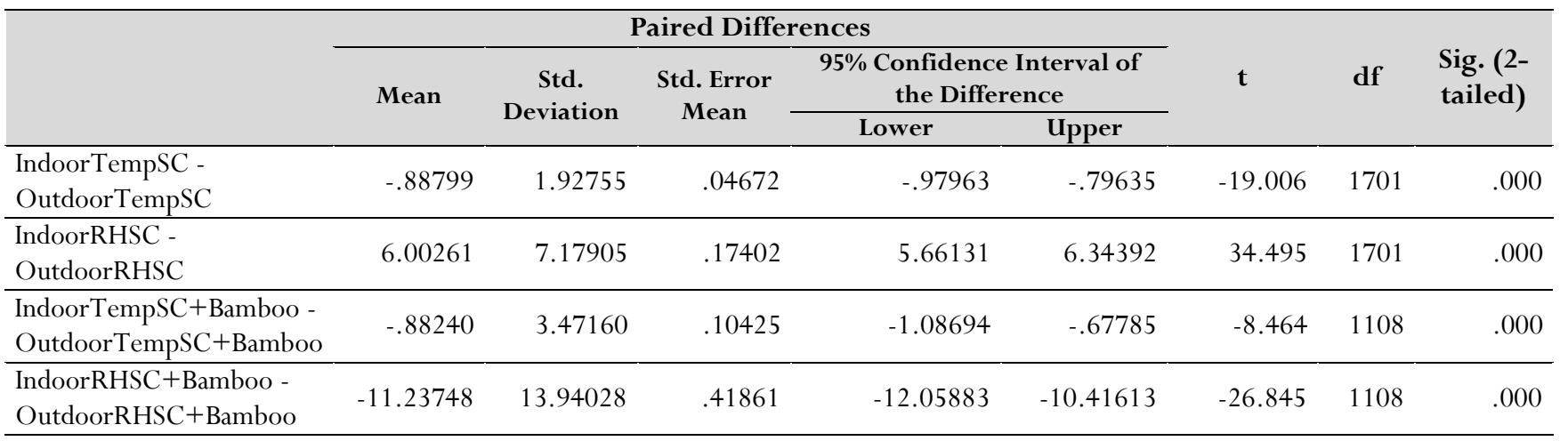

The daily pattern is also not acceptable to any range of comfort for Malaysians as reported by AbdulRahman (1997) and ZainAhmed et al. (2004) who give a range of 23.4 to $28^{\circ} \mathrm{C}$ of temperature and 54 to $76 \%$ of relative humidity. Hidayat and Munardi (2018) found that commercial facilities using a shipping container are less convenient for humans and animals especially cats and dogs as a standard recommendation for temperature and relative humidity indicated by American Veterinary Medical Association (AVMA) is in the range of between 15.5 to and $26.6^{\circ} \mathrm{C}$ and between 30 and $70 \%$, respectively.

Therefore, the effectiveness of shipping containers as liveable space in providing a comfortable indoor environment, particularly in the hot-humid tropics is not very convincing due to its lack of compatibility with the local climate conditions (Ismail et al., 2015). According to Wagner (2017), the building's thermoprofile shot during typical Malaysia overcast conditions shows that the outside temperature of the roof will increase up to $65^{\circ} \mathrm{C}$ and it is taking too much time to get rid of the heatwave. This situation is getting worse as the physical features of the shipping container are made of steel. Special attention should be paid to improve both the thermal resistance and hygro-thermal capacity of the envelope due to overheating risk and more humidity issues (Shen et al., 2020). Insulation plays an important role in converting the shipping container into habitual space although
Kamarazaly et al. (2017) found container construction is feasible in Malaysia. Brandt (2011) highlighted that R-value should be in line with a climatic condition as the interior of a shipping container gains extremely high temperature in summer, and vice versa during winter. Adequate insulation satisfies the thermal performance of housing units built with shipping containers (Adenaike, 2018). It should be refurbished not only by installing appropriate layers of insulation for controlling thermal, acoustic and fire protection, but also by equipping it with suitable vapor barriers, internal fittings and finishes that suit the local climate (Robinson et al., 2011).

Despite being regarded as one of the sustainable or green architectural alternatives that can provide low carbon footprint buildings, the ISO shipping containers in buildings consume higher energy (per square metre) and releases more carbon dioxide as compared to traditional buildings (Olivares, 2010). The overall contributions of the whole life cycle impacts with regard to six life cycle environmental impacts (LCEI) category indicators; cumulative energy demand (CED), water use, solid waste, global warming potential (GWP), acidification potential, and eutrophication potential, have increased significantly if the design life of a building is increased to 100 years (Islam et al., 2016). 
To achieve sustainable shipping container homes, the most effective strategy is the use of green roofs and green walls as energy consumption is reduced by $13.5 \%$ compared to the courtyard which reduces the total energy consumption by $3.6 \%$ (Taleb et al., 2019).

\subsection{Carbon Dioxide $\left(\mathrm{CO}_{2}\right)$}

The mean daily $\mathrm{CO}_{2}$ concentration values in a bare unit of shipping (BUSC) container varied from $440 \mathrm{ppm}$ to $540 \mathrm{ppm}$, as shown in Figure 7. The recorded values are in the range of between $296 \mathrm{ppm}$ and $661 \mathrm{ppm}$. By looking at the daily pattern, the mean value of $\mathrm{CO}_{2}$ concentrations reaches a peak at 8 am and starts to decrease until $3 \mathrm{pm}$. It gradually increases at $4 \mathrm{pm}$ afterward. A different situation was recognised in a shipping container that was insulated with untreated bamboo. The mean daily $\mathrm{CO}_{2}$ concentration values varied from $1,869 \mathrm{ppm}$ to 2,938 ppm as shown in Figure 8.

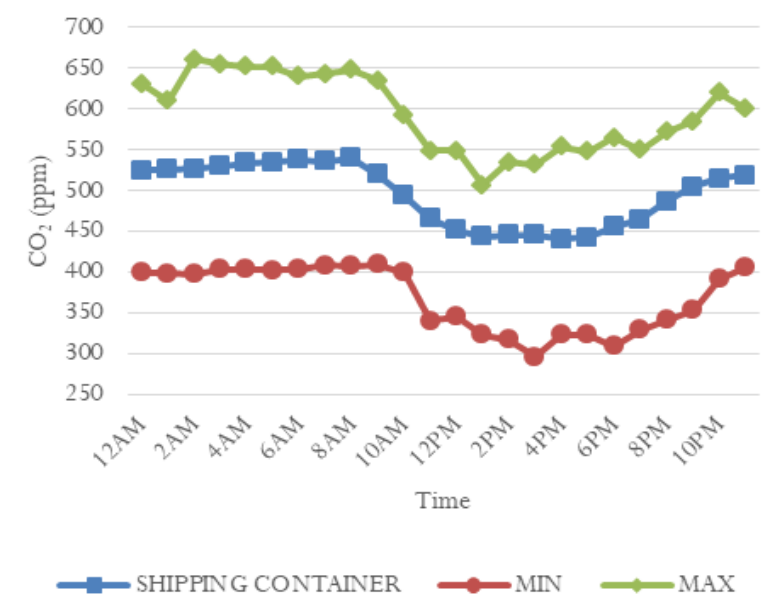

Figure 7 The daily pattern of $\mathrm{CO}_{2}$ concentration with minimum and maximum values in a bare unit of the shipping container (BUSC)

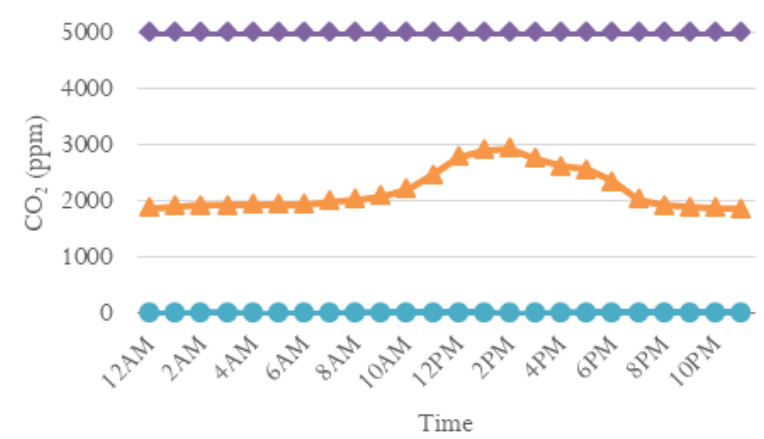

$\longrightarrow$ SHIPPING CONTAINER + BAMBOO $\longrightarrow$ MIN $\longrightarrow$ MAX

Figure 8 The daily pattern of $\mathrm{CO}_{2}$ concentration with minimum and maximum values in a shipping container with bamboo as insulation (IUBSC).

The minimum and the maximum recorded values were too extreme, exceeding 5,000 ppm which is beyond the capability of the data logger. The average value reached its highest point at 2 pm and declined subsequently.

As shown in Table 3, there was a significant difference $(\mathrm{t}=$ 25.538, df $=1,107, \mathrm{p}<.05$ ) of $\mathrm{CO}_{2}$ concentration values inside the bare unit of the shipping container (BUSC) and shipping container installed with untreated bamboo as insulation (IUBSC). The use of untreated bamboo as insulation drastically contributes to the Sick Building Syndromes (SBS) by shifting the indoor liveable space made from shipping containers into space under unhealthy conditions.

The maximum $\mathrm{CO}_{2}$ concentration occupational limits set by the developed countries is 5,000 ppm, while the Japan Society for Occupational Health sets the stringent maximum value at 1,500 ppm (Onset, 2017).

Table 3 Paired samples statistical analysis of $\mathrm{CO}_{2}$ concentration

\begin{tabular}{|c|c|c|c|c|c|c|c|c|}
\hline & \multicolumn{5}{|c|}{ Paired Differences } & \multirow{3}{*}{$\mathbf{t}$} & \multirow{3}{*}{ df } & \multirow{3}{*}{$\begin{array}{l}\text { Sig. (2- } \\
\text { tailed) }\end{array}$} \\
\hline & \multirow[t]{2}{*}{ Mean } & \multirow{2}{*}{$\begin{array}{c}\text { Std. } \\
\text { Deviation }\end{array}$} & \multirow{2}{*}{$\begin{array}{l}\text { Std. Error } \\
\text { Mean }\end{array}$} & \multicolumn{2}{|c|}{$\begin{array}{l}\text { 95\% Confidence Interval } \\
\text { of the Difference }\end{array}$} & & & \\
\hline & & & & Lower & Upper & & & \\
\hline $\mathrm{CO}_{2} \mathrm{SC}-\mathrm{CO}_{2} \mathrm{SCBamboo}$ & -1664.644 & 2169.708 & 65.183 & -1792.540 & -1536.749 & -25.538 & 1107 & .000 \\
\hline
\end{tabular}

According to the Department of Occupational Safety and Health (2010), 1,000 ppm is the ceiling limit that shall not be exceeded at any time. The maximum $\mathrm{CO}_{2}$ concentration occupational limits set by the developed countries is 5,000 ppm, while the Japan Society for Occupational Health sets the stringent maximum value at 1,500 ppm (Onset, 2017). According to the Department of Occupational Safety and Health (2010), 1,000 ppm is the ceiling limit that shall not be exceeded at any time. Headaches, sleepiness, stagnant, stale, stuffy air, poor concentration, loss of attention, increased heart rate and slight nausea are the potential health problems when the concentration level of $\mathrm{CO}_{2}$ is in the range of 2,000 to 5,000 ppm (Wisconsin Department of Health Services, 2018). With the $\mathrm{CO}_{2}$ concentration level exceeding $5,000 \mathrm{ppm}$, it indicates unusual air conditions where high levels of other gases could also present and the toxicity of oxygen deprivation could occur (Bonino, 2016).

Concerning the untreated bamboo as insulation, it must be waterproof and should not be susceptible to mould or fungi (Joshi, 2008). The mould can spread in buildings as the fungus 
experiences additional water events, while the colonies remain viable long after a water source has been removed and it remains toxic over extended periods (Straus, 2009). According to Sun et al. (2013), mould has a significant risk factor for nose irritation. Humidity should be measured more often indoors as high air humidity is related to more SBS symptoms (Smedje et al., 2017).

Even the recorded values in a bare unit of the shipping container (BUSC) are within the indoor range target of the $\mathrm{CO}_{2}$ hazard scale; which is in the range of $600 \mathrm{ppm}$ to $1,000 \mathrm{ppm}$, so further attention is crucial. According to the European Standard (EN 13779, 2007), this range is classified as moderate indoor air quality. Exposure to $\mathrm{CO}_{2}$ levels greater than 800 ppm makes the occupants likely to report more eye irritation or upper respiratory symptoms (Tsai et al., 2012). The consequences include a lower rate of productivity, tiredness and distracted decision-making (Ghaffarianhoseini et al., 2018). As reported by Jaber et al. (2017), decreasing $\mathrm{CO}_{2}$ levels from $1,800 \mathrm{ppm}$ and/or 1,000 ppm to $600 \mathrm{ppm}$ significantly improved the performance of adult female students in a memory and attention task.

The prevalence of several SBS symptoms can be significantly reduced by increasing the ventilation rates per person (Erdmann et al., 2002). According to Adenaike (2018), the aspect of volumetric air changes becomes more relevant if the units are occupied by several people to reduce the heat generated by human metabolism and moisture from respiration by an individual. The improvement of ventilation systems with a proper design and an efficient room layout is the key strategy to address the issues of SBS (Ghaffarianhoseini et al., 2018). With the adaptation of natural ventilation, the prevalence of SBS symptoms is less as compared to air-conditioned buildings or buildings with simple mechanical ventilation (Seppanen and Fisk, 2002). The recycling of air in rooms is one of the main causes of SBS (Jafari et al., 2015). The fresh air is required to supply air for respiration, as well as to dilute carbon dioxide and other contaminants (Rostron, 2008). The airflow rate of 5 cubic feet per minute (CFM) per person in a standard office environment and up to $15 \mathrm{CFM}$ in smoking areas or areas adjacent to manufacturing or warehousing areas are recommended by American Society of Heating, Refrigerating and Air-Conditioning Engineers (Heinkel, 2016).

Well-treated bamboos as insulation and perfect ventilation are not the ultimate accomplishment in developing liveable space made from the recycled shipping container. Other contributing factors need high consideration as mentioned earlier, including personal factors, job category, type of work, psychosocial factors, building factors, and building-related factors. It is impossible to provide one environment that suits a large proportion of the population due to the diverse individuals' requirements for indoor air quality. The development of SBS becomes prominent to the individuals who are unable to adapt to, or alter the surrounding environments (Burge, 2004). However, it is believed that the ability to handle indoor air quality issues becomes key to a healthy, comfortable and sustainable environment.

\section{Conclusion}

From the sustainability perspective, the shipping container is not applicable to be used as a building material to build a liveable space due to the incompatibility with the hot and humid conditions of the equatorial climate. Conversely, there is a potential in bamboo as insulation but it needs a holistic attention on the quality aspect. Only matured bamboos should be used with an appropriate treatment to extend the life span and allowing them to perform as good insulation.

The range of $18^{\circ} \mathrm{C}$ to $42^{\circ} \mathrm{C}$ of temperature and $56 \%$ to $100 \%$ of relative humidity values were recorded in both conditions, which are in a bare unit of the shipping container (BUSC) and with the installation of untreated bamboo as insulation (IUBSC). These values force the full utilisation of the mechanical cooling system in the future to sustain the comfort level that indirectly increases the carbon footprint through the higher usage of electricity. Referring to the 24 hours' average profile, higher indoor temperature values were recorded up to $35^{\circ} \mathrm{C}$ in a bare unit of the shipping container (BUSC) as compared to the outdoor. The maximum difference exceeds $4^{\circ} \mathrm{C}$. Meanwhile, untreated bamboo as insulation (IUBSC) is able to reduce indoor temperature and make it equivalent to the outdoor, which is $30^{\circ} \mathrm{C}$. There are some differences in a certain hour but with a smaller maximum value, $2.5^{\circ} \mathrm{C}$. The decaying process of untreated bamboo forces the relative humidity values to the maximum, 100\%. Statistically, there are significant differences in the temperature and relative humidity values between the indoor and outdoor of the shipping container in both conditions. A significant difference in $\mathrm{CO}_{2}$ concentration levels was also discovered inside the shipping container before and after the installation of untreated bamboo as insulation. In a bare unit of the shipping container (BUSC), the mean daily $\mathrm{CO}_{2}$ concentration values varied from $440 \mathrm{ppm}$ to 540 ppm and exceeded $661 \mathrm{ppm}$ as a maximum recorded value. With the insulation made from the bamboo (IUBSC), the mean values were in the range of $1,869 \mathrm{ppm}$ to $2,938 \mathrm{ppm}$. Remarkably, the concentration of $\mathrm{CO}_{2}$ levels reached up to $5,000 \mathrm{ppm}$ at the most intervals especially during the early days after the installation. Concerning Sick Building Syndrome (SBS), there is no direct contribution by the shipping container (BUSC) as compared to the addition of untreated bamboo as insulation (IUBSC) that indicates a significant contribution to SBS.

To evaluate the potential of the shipping container and bamboo as a sustainable construction material in a rigorous manner, further research should be done by using data loggers that are able to record a higher level of concentration with various parameters of indoor and outdoor air quality. This also includes thermal comfort parameters which are air temperature, relative humidity, air speed and mean radiant temperature. If possible, all the measurements should be done concurrently for a longer period with multiple replicates to get comprehensive findings. Different treatments to bamboo are required to enhance the quality and reduce the risk of SBS while maintaining sustainability features. The natural ventilation aspect should be included to minimise the energy usage for sustaining the comfort level of liveable space made from the shipping container, especially in the equatorial climate region. 


\section{Acknowledgements}

The authors would like to thank Pusat Penyelidikan Bioteknologi Glami Lemi, Universiti Malaya (PPBGL UM), which located at Jelebu, Negeri Sembilan for their permission to carry out the research within their premises. This work was financially supported by Institut Pengurusan dan Pemantauan Penyelidikan (IPPP), Universiti Malaya under BKP Grant (BK010-2015).

\section{References}

AbdulRahman, S. (1997). A Study of Thermal Comfort in Naturally Ventilated Classrooms: Toward New Indoor Temperature Standards. Proceedings of the 4th Asia-Pacific Conference on the Built Environment. November 3-6, 1997, Kuala Lumpur, Malaysia.

Adenaike, F.A. (2018). An assessment of thermal performance of office units built with shipping containers around Lagos. International Journal of Scientific \& Engineering Research. 9(2): 44-72.

Aditya, L., Mahlia, T.M.I., Rismanchi, B., Ng, H.M., Hasan, M.H., Metselaar, H.S.C., Muraza, O., \& Aditya, H.B. 2017. A review on insulation materials for energy conservations in buildings. Renewable and Sustainable Energy Reviews. 73: 1352-1365.

Adreena, I. (2017). 5 Unique Malaysian Container Hotels That Deserve Your Attention. Retrieved March, 2020, from http://www.rojakdaily.com/lifestyle/article/3389/5-unique-

malaysian-container-hotels-that-deserve-your-attention

Ahmad, S.A. (2008). Kuala Lumpur: A hot humid climate. In R. Hyde (ed.) Bioclimatic housing: Innovative designs for warm climates. 269293. Earthscan: UK.

Alaniazul. (2016). Have the night of your life at one of these 5 quirky container hotels in KL \& Selangor!. Retrieved March, 2020, from https://discoverkl.com/2016/08/23/container-hotel-kl-selangor/

Apte, M.G., Fisk, W.J., \& Daisey, J.M. (2000). Associations between indoor $\mathrm{CO} 2$ concentrations and sick building syndrome symptoms in U.S. office buildings: An analysis of the 1994-1996 BASE study data. Indoor Air. 10(4): 246-257.

Asdrubali, F., D’Alessandro, F., \& Schiavoni, S. (2015). A review of unconventional sustainable building insulation materials. Sustainable Materials and Technologies. 4: 1-17.

Askarinejad, S., Kotowski, P., Shalchy, F., \& Rahbar, N. (2015). Effects of humidity on shear behavior of bamboo. Theoretical and Applied Mechanics Letters. 5(6): 236-243.

Bal, L.M., Kar, A., Satya, S., \& Naik, S.N. (2010). Drying kinetics and bamboo shoot slices undergoing microwave drying. International Journal of Food Science \& Technology. 45(11): 2321-2328.

Basrawi, F., Ibrahim, H., Taib, M.Y., \& Lee, G.C. (2013). Optimum thickness of wall insulations and their thermal performance for buildings in Malaysia climate. International Journal of Automotive and Mechanical Engineering. 8: 1207-1217.

Bernardo, L.F.A., Oliveira, L.A.P., Nepomuceno, M.C.S., \& Andrade, J.M.A. (2013). Use of refurbished shipping containers for the construction of housing buildings: Details for the structural project. Journal of Civil Engineering and Management. 19(5): 628-646.

Bonino, S. (2016). Carbon dioxide detection and indoor air quality control. Retrieved March, 2020, from https: / / ohsonline.com/articles/2016/04/01/carbon-dioxide-detectionand-indoor-air-quality-control.aspx

Botes, A.W. (2013). A Feasibility Study of Utilising Shipping Containers to Address the Housing Backlog in South Africa. M.Eng Thesis. Stellenbosch University: South Africa.

Brandt, K.A. (2011). Plugging, in: Reinterpreting the Traditional Housing Archetype within a Community Using Shipping Containers. M.Sc. Thesis. University of North Carolina: Greensboro.

Bruges, J.B., Vieira, G.B., Orellana, D.R., \& Togo, I. (2018). Parameter of thermal resistance of bamboo multilayer wall. Magazine of Civil Engineering. 83(7): 92-101.

Buchmeier, M., Slawik, H., Tinney, S., \& Bergmann, J. (2010). Container atlas: A practical guide to container architecture. Berlin: Gestalten.

Burge, P.S. (2004). Sick building syndrome. Occupational \& Environmental Medicine. 61(2): 185-190.

Chuen, K.W., Qian, C.W., Hwa, C.C., \& Fouladi, M.H. (2015). Effect of using coconut fibre and polypropylene for thermal insulation in a flat plate collector. Journal of Engineering Science and Technology. 41-49.

Crook, B., \& Burton N.C. (2010). Indoor moulds, sick building syndrome and building related illness. Fungal Biological Reviews. 24(3): 1 8 .

Dahlan, N.D., Jones, P.J., Alexander, D.K., Salleh, E., \& Alias, J. (2009). Evidence base prioritisation of indoor comfort perceptions in Malaysian multi-storey hostels. Building and Environment. 44(10): 21582165 .

Department of Occupational Safety and Health. (2010). Industry code of practice on indoor air quality 2010. Malaysia: Ministry of Human Resources.

EN 13779. (2007). European Standard. Ventilation for non-residential buildings - Performance requirements for ventilation and room conditioning systems.

Erdmann, C.A., Steiner, K.C., \& Apte, M.G. (2002). Indoor carbon dioxide concentrations and sick building syndrome symptoms in the base study revisited: Analyses of the 100 building dataset. Proceedings of Indoor Air - 9th International Conference on Indoor Air Quality and Climate. June 30 - July 5, 2002, Monterey, California, USA.

Fisk, W.J., Mirer, A.G. \& Mendell, M.J. (2009). Quantitative relationship of sick building syndrome symptoms with ventilation rates. Indoor Air. 19: 159-165.

Gallegos-Villela R.R., Sánchez-Medrano M.T., Avalos-Perez, M.A. Izquierdo-Kulich E.F., \& Suarez-Dominguez E.J. (2016). Thermal conductivity of bamboo (Guadua velutina) in earthen construction of sustainable structures. International Journal of Engineering and Technical Research. 5(3): 29-31. 
Ghaffarianhoseini, A., AlWaer, H., Omrany, H., Ghaffarianhoseini, A., Alalouch, C., Clements-Croome, D., \& Tookey, J. (2018). Sick building syndrome: are we doing enough?. Architectural Science Review. 61(3): 99121.

Heinkel, N. (2016). Sick building syndrome: What it is and tips for prevention. Retrieved March, 2020, from https: / / ohsonline.com/articles/2016/10/01/sick-building-

syndrome.aspx

Hidayat, M.S., \& Munardi. (2018). The shipping container as commercial building: The process of construction and thermal comfort conditions. International Journal of Recent Engineering Research and Development. 3(5): 181-189.

Hong, T., Kim, J., \& Lee, M. (2018). Integrated task performance score for the building occupants based on the $\mathrm{CO}_{2}$ concentration and indoor climate factors changes. Applied Energy. 228: 1707-1713.

Hong, Y. (2017). A study on the condition of temporary housing following disasters: Focus on container housing. Frontiers of Architectural Research. 6: 374-383.

International Organization for Standardization (ISO). (1995). ISO 668:1995. Series 1 - Container shipping. Classification, dimensions and calculations. Geneva, Switzerland.

Islam, H., Zhang, G.T., Setunge, S., \& Bhuiyan, M.A. (2016). Life cycle assessment of shipping container home: A sustainable construction. Energy and Buildings. 128: 673-685.

Ismail, M., Al-Obaidi, K.M., Rahman, A.M.A., \& Ahmad, M.I. (2015). Container architecture in the hot-humid tropics: Potential and constrains. In Teng Tjoon Tow, Yusri Yusup, Widad Fadhlullah (ed.) Proceedings of the $4^{\text {th }}$ ICERT 2015: International Conference On Environmental Research and Technology: Exploring The Frontiers in Environmental Science and Technology Research, 27-29 May 2015, Park Royal Penang, Malaysia.

Jaber, A.R., Dejan, M., \& Marcella, U. (2017). The effect of indoor temperature and $\mathrm{CO}_{2}$ levels on cognitive performance of adult females in a university building in Saudi Arabia. Energy Procedia. 122: 451-456

Jafari, M.J., Khajevandi, A.A., Najarkola, S.A.M., Yekaninejad, M.S., Pourhoseingholi, M.A., Omidi, L., \& Kalantary, S. (2015). Association of Sick Building Syndrome with Indoor Air Parameters. Tanaffos. 14(1): 55-62.

Jamaludin, A.A., Hussein, H., Keumala, N., \& Ariffin, A.R.M. (2017). Post occupancy evaluation of residential building with bioclimatic design strategies in tropical climate condition of Malaysia. Jurnal Teknologi. 79(4): 113-122.

Joshi, S.M. (2008). The sick building syndrome. Indian Journal of Occupational \& Environmental Medicine. 12: 61-64.

Jusoh, N.Z., Zakaria, A.M., Ahmad, M., \& Azmi, I. (2013). Thermal Conductivity of Akar Bamboo (Dendracalamus pendulus) and Semantan Bamboo (Gigantochloa scortechinii). Advanced Materials Research. 748: 160164.

Kamarazaly, M.A., Xu, T.H., \& Yaakob, A.M. (2017). A feasibility study on container construction in Malaysia. Journal of Built Environment, Technology and Engineering. 3: 110-119.
KL Now. (2016). 10 Super cool container hotels in Malaysia. Retrieved March, 2020 from https://www.klnow.com.my/english/super-coolcontainer-hotels-malaysia/

Levinson, M. (2016). The box: How the shipping container made the world smaller and the world economy bigger. ( $2^{\text {nd }}$ ed). Princeton University Press: US.

Martinez-Garcia, M. (2014). Alternative housing: The shipping container home. Center for Realtor Technology. 1-22.

Moghimi, S., Bakhtyar, B., Azizpour, F., Sopian, K., Lim, Ch., Mat, S., \& Salleh, E. (2013). Maximization of energy saving and minimization of insulation cost in a tropical hospital: A case study in Malaysia. WSEAS Transactions on Environment and Development. 9: 105-115.

Nguyen, D.M., Grillet, A., Diep, T.M.H., Bui, Q.B., \& Woloszyn, M. (2018). Influence of thermo-pressing conditions on insulation materials from bamboo fibers and proteins based bone glue. Industrial Crops \& Products. 111: 834-845.

Nwoke, O.A., \& Ugwuishiwu, B.O. (2011). Local bamboo and earth construction potentials for provision of affordable structures in Nigeria. International Journal of Sustainable Construction Engineering and Technology. 2(2): 17-31.

Olivares, A.A.P. (2010). A Comparative Life Cycle Analysis of Container Architecture for Residential Structures. M.Arch Thesis. Victoria University of Wellington: New Zealand.

Oloto, E., \& Adebayo, A.K. (2012). Building with shipping containers: A sustainable approach to solving housing shortage in Lagos Metropolis. Proceeding of the $7^{\text {th }}$ International Conference on Innovation in Architecture, Engineering \& Construction. August, 15-17, Brazil.

Onset. (2017). Onset Hobo data loggers: Measure CO2 to improve ventilation/IAQ. USA: Onset Computer Corporation.

Pena, J., \& Schuzer, K. (2012). Design of reusable emergency relief housing units using general purpose shipping containers. International Journal of Engineering Research and Innovation. 4(2): 55-64.

Perrucci, D.V., Vazquez, B.A., \& Aktas, C.B. (2016). Sustainable Temporary Housing: Global Trends and Outlook. Procedia Engineering. 145: 327-332.

Radwan, A.H. (2015). Containers Architecture Reusing Shipping Containers in making creative Architectural Spaces. International Journal of Scientific \& Engineering Research. 6(11): 1562-1577.

Reif, M., Zach, J., \& Hroudová, J. (2016). Studying the properties of particulate insulating materials on natural basis. Procedia Engineering. 151: 368-374.

Robinson, A., Austen, S., \& Gibb, A. (2011). Design and Building Performance of Intermodal Shipping Container Construction. Proceedings of the 10th International Detail in Design in Architecture Conference, Istanbul. October 27-28, 2011, Istanbul, Turkey.

Rostron, J. (2008). Sick building syndrome: A review of causes, consequences and remedies. Journal of Retail \& Leisure Property. 7(4): 291303.

Sekhar, A.C., \& Bhartari, R.K. (1960). Studies of strength of bamboo. A note on its mechanical behaviour. India Forester. 86(5): 296-301. 
Seppanen, O., \& Fisk, W.J. (2002). Relationship of SBS-symptoms and ventilation system type in office buildings. Proceedings of Indoor Air 9th International Conference on Indoor Air Quality and Climate. June 30 - July 5, 2002, Monterey, California, USA.

Shen, J., Copertaro, B., Zhang, X., Koke, J., Kaufmann, P., \& Krause, S. (2020). Exploring the potential of climate-adaptive container building design under future climates scenarios in three different climate zones. Sustainability. 12(1): 108.

Skov, P., Valbjorn, O., \& Pedersen, B.V. (1990). Influence of indoor climate on the sick building syndrome in an office environment. Scandinavian Journal of Work Environmental \& Health. 16: 363-371.

Smedje, G., Wang, J., Norbäck, D., Nilsson, H., \& Engvall, K. (2017). SBS symptoms in relation to dampness and ventilation in inspected singlefamily houses in Sweden. International Archives of Occupational and Environmental Health. 90(7): 703-711.

Snow, S., Boyson, A.S., Paas, K.H.W., Gough, H., King, M., Barlow, J., Noakes, C.J., \& Schraefel, M.C. (2019). Exploring the physiological, neurophysiological and cognitive performance effects of elevated carbon dioxide concentrations indoors. Building and Environment. 156: 243-252.

Straus, D.C. (2009). Molds, mycotoxins and sick building syndrome. Toxicology and Industrial Health. 25(9-10): 617-635.

Sun, Z., Mei, H., \& Ni, R. (2017). Overview of Modular Design Strategy of the Shipping Container Architecture in Cold Regions. IOP Conference Series: Earth and Environmental Science. 63: 012035.

Sun, Y., Zhang, Y., Bao, L., Fan, Z., Wang, D., \& Sundell, J. (2013). Effects of gender and dormitory environment on sick building syndrome symptoms among college students in Tianjin, China. Building and Environment. 68: 134-139.

Taleb, H., Elsebaei, M. \& El-Attar, M. 2019. Enhancing the sustainability of shipping container homes in a hot arid region: A case study of Aswan in Egypt. Architectural Engineering and Design Management. 15(6): 459-474.
Tsai, D.H., Lin, J.S., \& Chan, C.C. (2012). Office workers' sick building syndrome and indoor carbon dioxide concentration. Journal of Occupational and Environmental Hygiene. 9(5): 345-351.

Uittenbroek, C., \& Macht, W. (2009). Sustainable container: Costeffective student housing. Quarterly \& Urban Development Journal. $4^{\text {th }}$ Quarter: 53-60.

Vijayalaxmi, J. (2010). Towards sustainable architecture - A case with Greentainer. Local Environment: The International Journal of Justice. 15(3): 245-259.

Volf, M., Divis, J., \& Havlik, F. (2015). Thermal, moisture and biological behaviour of natural insulating materials. Energy Procedia. 78: 1599-1604.

Wagner, K. (2017). A tropically adapted green and energy-efficient building: How to create your own triple green sustainable house. Kuala Lumpur: University of Malaya Press.

Wang, J.S., Demartino, C., Xiao, Y., \& Li, Y.Y. (2018). Thermal insulation performance of bamboo- and wood-based shear walls in lightframe buildings. Energy \& Buildings. 168: 167-179.

Wijerathne, H.A.N., Karunasena, G.I., \& Mallawaaracchchi, B.H. (2012). Study on sick building syndrome in office environment. Retrieved March, 2020, from http://www.irbnet.de/daten/iconda/CIB_DC25151.pdf

Wisconsin Department of Health Services. (2018). Carbon dioxide Health effects. Retrieved March, 2020 from https: / / www.dhs. wisconsin.gov/chemical/carbondioxide.htm

Zain-Ahmed A., Abdul Rahman, S., \& Shahrani S. (2004). Indoor Air Quality in a Malaysian Middle Class Home. Proceedings of the Conference on Scientific and Social Research. May 19-21, 2004, Kuching, Sarawak, Malaysia.

Zhang, G., Setunge, S., \& van Elmpt, S. (2014). Using shipping containers to provide temporary housing in post-disaster recovery: Social case study. Procedia Economics and Finance. 18: 618-625. 